\title{
Perilaku Subordinasi, Kekerasan, dan Penjinakan (Cooptation) Tokoh Perempuan dalam Novel Putri I Karya Putu Wijaya: Kajian Feminisme
}

\section{Ni Made Ignityas Prima Astuti ${ }^{1 *}$}

${ }^{1}$ Program Studi Manajemen, Sekolah Tinggi Bisnis Putra Harapan, Jembrana, Indonesia *e-mail: Ignityas.win@gmail.com

\begin{abstract}
Abstrak
Ketidakadilan gender yang mengakibatkan terjadinya marjinalisasi terhadap perempuan, perempuan menjadi pihak yang dipinggirkan. Penelitian ini memiliki tujuan menunjukkan unsur-unsur intrinsik dan ekstrinsik dalam novel Putri I karya Putu Wijaya, perilaku subordinasi, kekerasan dan penjinakan (Cooptation) tokoh perempuan. Rancangan penelitian ini adalah deksriptif kualitatif. Sumber data yang digunakan adalah novel Putri I karya Putu Wijaya yang diterbitkan tahun 2004. Metode yang digunakan yaitu dokumentasi dengan menggunakan teknik pencatatan dokumen. Data yang didapat berupa kutipan tentang unsur intrinsik dan ekstrinsik serta perilaku subordinasi, kekerasan dan penjinakan(cooptation) tokoh perempuan dalam novel Putri dengan menggunakan kajian feminisme. Hasil penelitian adalah unsur yang terdapat dalam novel Putri I, yaitu unsur intrinsic yang mencakup tema tentang permasalahan gender dengan menggunakan alur campuran, latar (tempat, waktu, suasana) terdapat dalam novel untuk menghidupkan cerita. Gaya bahasa dalam novel penulis ambil secara acak yang meliputi majas personfikasi sebanyak $50 \%$, hiperbola sebanyak $16 \%$, simile $8 \%$, metafora sebanyak $25 \%$. Unsur ekstrinsik terdapat biografi pengarang Putu Wijaya, faktor adat, tradisi, religi, dan politik. Perilaku ketidakadilan gender berupa subordinasi kekerasan, dan penjinakan tokoh perempuan dalam novel Putri I diperoleh hasil sebanyak 18 data, yaitu subordinasi 5 data, kekerasan 5 data, dan yang paling banyak adalah penjinakan sebanyak 8 data.
\end{abstract}

Kata kunci: intrinsik, ektrinsik, ketidakadilan gender, feminisme

\begin{abstract}
Gender injustice which results in the marginalization of women, women become the marginalized parties. This study aims to show the intrinsic and extrinsic elements in Putri I novel by Putu Wijaya, subordination behavior, violence and taming (Cooptation) of female characters. This research design is descriptive qualitative. The data source used is the Putri I novel by Putu Wijaya published in 2004. The method used is documentation using document recording techniques. The data obtained are in the form of quotes about intrinsic and extrinsic elements as well as subordination, violence and cooptation behavior of female characters in the Putri I novel using feminist studies. The result of the research is the elements contained in the Putri I novel, namely the intrinsic elements that cover the theme of gender issues by using a mixed plot, setting (place, time, atmosphere) contained in the novel to bring the story to life. The language style in the novel, the writer takes randomly, includes personification as much as 50\%, hyperbole as much as $16 \%$, simile $8 \%$, metaphor as much as $25 \%$. Extrinsic elements are the biography of the author Putu Wijaya, the factors of custom, tradition, religion and politics. Gender injustice in the form of violence subordination and taming female characters in the Putri I novel obtained 18 data, namely 5 data subordination, 5 data violence, and the most taming is 8 data.
\end{abstract}

Keywords: intrinsic, extrinsic, gender injustice, feminism.

\footnotetext{
${ }^{*}$ Corresponding author.

Received 30 Januari 2021; Accepted 1 Maret 2021; Available online 8 April 2021 (C) 2021 MI All Rights Reserved
} 


\section{Pendahuluan}

Karya sastra merupakan gambaran kehidupan manusia dan merupakan hasil rekaan seseorang. Hasil rekaan tersebut bukan hanya sekedar imajinasi, melainkan juga diwarnai oleh latar belakang kehidupan sosial masyarakat dan keyakinan pengarang (Burhanuddin, Susiawati, \& Ernawati, 2017; Sari, 2017). Ada beberapa pandangan mengenai karya sastra, salah satunya yang menyebutkan bahwa karya sastra juga menggambarkan ekspresi dari kehidupan nyata. Kehidupan di dalam karya sastra adalah kehidupan yang telah diwarnai dengan sikap penulisannya, latar belakang pendidikannya, keyakinan dan sebagainya (Fatah, Widodo, \& Rohmadi, 2018; Helda, 2016). Selain itu karya sastra juga merupakan hasil penyampaian ide-ide dan pandangan tentang kehidupan manusia yang dituangkan secara kreatif dan dikemas dalam bentuk yang indah oleh sastrawan. Karya sastra merupakan karya kreatif sehingga sastra harus mampu melahirkan suatu kreasi yang indah dan berusaha menyalurkan kebutuhan keindahan manusia. Salah satu karya sastra yang saat ini terkenal adalah novel. Novel adalah sebuah cerita yang berkaitan dengan peristiwa nyata atau fiksional yang dibayangkan pengarang melalui pengamatannya terhadap realitas (Qadriani, 2016; Wahyuni, Supratno, \& Kamidjan, 2019). Novel adalah karya sastra yang memiliki dua unsur, yaitu intrinsik dan ekstrinsik keduanya saling terkait sebagai pengaruh timbal balik dalam literatur. Novel juga dibentuk oleh berbagai unsur, diantaranya penokohan, plot/alur, latar/setting, sudut pandang dan tema. Semua unsur tersebut dianggap penting dalam membangun sebuah karya yang utuh. Dalam novel, para sastrawan dapat menyampaikan berbagai tema. Tema yang banyak diangkat dalam alur cerita novel tentang permasalahan gender.

Gender secara umum digunakan sebagai alat mengidentifikasi antara laki-laki dan perempuan dari segi sosial-budaya (Daeng, 2012; Ulfah, Garim, \& Sultan, 2019). Permasalahan gender ini berkaitan dengan feminisme. Gerakan feminisme ini merupakan usaha untuk memecahkan masalah ketimpangan gender dan berupaya mewujudkan pemahaman tentang kesetaraan gender yang sebenarnya (Kurniawan \& Suyitno, 2020; Putri, 2020). Permasalahan gender ini merucut pada ketidakadilan gender yang mengakibatkan: 1) terjadinya marjinalisasi terhadap perempuan, perempuan menjadi pihak yang dipinggirkan. 2) subordinasi terhadap wanita, keadaan ini menganggap wanita tidak penting dan kedudukan wanita berada di bawah laki-laki. 3) beban kerja yang berlebihan. 4) streotipe terhadap perempuan. 5) Kekerasan terhadap wanita. Berdasarkan permasalahan-permasalahan tersebut, penulis memilih melakukan penelitian yang berkaitan dengan kehidupan perempuan dalam karya sastra yang berfokus pada ketidakadilan gender berupa perilaku subordinasi, kekerasan, dan penjinakan tokoh perempuan. Pengamatan awal yang dilakukan, terdapat bagian yang ditonjolkan dalam novel berupa ketidakadilan gender yang berkaitan dengan perilaku subordinasi, kekerasan dan penjinakan yang dilakukan terhadap tokoh perempuan dalam cerita novel Putri I karya Putu Wijaya.Penelitian ini akan mengungkapkan berbagai perilaku yang dialami tokoh perempuan berupa subordinasi, kekerasan, dan penjinakan melalui konflikkonflik yang dialami dengan menggunakan kajian feminisme.

Ada dua pertimbangan penulis meneliti Novel Putri I yaitu, pertama karena penulis novel Putri I yakni Putu Wijaya adalah sastrawan Indonesia yang produktif menghasilkan karya sastra, ragam karyanya berupa cerpen, novel, drama, maupun skenario film dan aktif mengangkat tema mengenai gender. Pertimbangan kedua karena novel Putri I diindikasikan mengandung beragam hal yang menyangkut tradisi Bali dan di dalamnya terdapat konflik-konflik menarik terkait ketidakadilan gender, terutama perilaku subordinasi, kekerasan dan penjinakan yang dihadapi tokoh perempuan dalam novel. Sebelum penelitian ini dilakukan, pernah beberapa ada penelitian sejenis yang dilakukan oleh Mulyaningsih (2015) melakukan penelitian dengan judul Kajian Feminispada Novel Ronggeng Dukuh Paruk dan Perempuan Berkalung. Berdasarkan hasil analisis dapat disimpulkan bahwa RDP dan PBS sama-sama mengangkat tentang perempuan, 
terutamaanak perempuan. Ronggeng Dukuh Paruk mengeksploitasi anak perempuan dari segi ekonomi sedangkan Perempuan Berkalung Surban tidak memberi kesempatan kepada anak perempuan untuk menentukan kehidupannya sendiri. Kedua novel tersebut sama-sama menggambarkan ketidakadilan pada anak perempuan. Persamaan penelitian tersebut dengan penelitian yang penulis lakukan terdapat pada kajian yang digunakan, yaitu sama-sama menggunakan kajian feminisme dengan metode penelitian deskriptif kualitatif. Adapun perbedaannya terdapat pada subjek yang digunakan, penelitian ini mengkaji novel dengan kajian feminisme secara umum. Sedangkan penelitian yang peneliti lakukan mengkaji tentang perilaku subordinasi, kekerasan dan penjinakan tokoh perempuan dalam novel. Selain itu novel yang digunakan pun berbeda. Novel yang digunakan penulis adalah novel Putri karya Putu Wijaya, sedangkan novel yang digunakan pada penelitian tersebut adalah Novel Ronggeng Dukuh Paruk dan Perempuan Berkalung Surban.

Penelitian yang dilakukan oleh Liasna \& Ansari (2016) menyatakan bahwa Kesetaraan gender dalam novel Padang Bulan berupa akses, partisipasi, dan kontrol. Penelitian tersebut sejalan dengan penelitian yang penulis lakukan. Ada beberapa persamaan, yaitu kajian yang dipilih menggunakan kajian feminisme. Selain itu metode sama-sama menggunakan metode deskriptif kualitatif. Perbedaan penelitian ini terletak pada pembahasan. Penelitian yang dilakukan membahas tentang perspektif gender sedangkan pembahasan yang penulis lakukan tentang perilaku subordinasi, kekerasan dan penjinakan tokoh perempuan dalam novel. Selain itu, objek yang digunakan adalah novel Padang Bulan Cinta di dalam Gelas Karya Andrea Hirata.

Penelitian yang dilakukan oleh Susanti (2013) menunjukkan bahwa Subordinasi dan stereotipe membuat perempuan mendapatkan perlakuan semena-mena, karena adanya anggapan bahwa kekuasaan terbesar ada pada kaum laki-laki dan perempuan harus tunduk terhadap laki-laki.Perempuan yang dianggap lemah dan tidak mampu melakukan segala sesuatunya sendiri, membuat perempuan selalu bergantung dan mengakibatkan anggapan bahwa perempuan tidak layak untuk menjadi seorang pemimpin.Asumsi bahwa perempuan bersolek dalam rangka memancing lawan jenisnya. Maka setiap kasus kekerasan seksual atau pelecehan seksual selalu dikaitkan dengan label ini dengan semakin merendahkan kedudukan perempuan, maka akan semakin diindahkannya kesempatan yang dimiliki perempuan di dalam masyarakat karena merasa di nomor duakan dan tidak dianggap penting. Marginalisasi membuat kedudukan perempuan inferior dan berdampak pada pekerjaan perempuan yang tidak terlalu bagus (baik dari gaji, jaminan kerja, status pekerjaaan). Penelitian tersebut sejalan dengan penelitian yang penulis lakukan. Adapun persamaannya terletak pada objek penelitian yang menganalisis ketidakadilan gender, begitu pula dengan penulis yang menganalisis perilaku subordinasi, kekerasan, dan penjinakan tokoh perempuan. Ketika bentuk perilaku tersebut juga termasuk dalam ketidakadilan gender. Adapun perbedaannnya terdapat dalam subjek penelitian, yaitu penelitian yang digunakan oleh Endah Susanti merupakan Novel Kupu-kupu Malam Karya Achmad Munif sedangkan penulis menggunakan Novel Putri I karya Putu Wijaya.

Ketiga penelitian sejenis tersebut penulis gunakan sebagai refrensi dalam penyempurnaan penelitian yang penulis lakukan. Namun, dari penelitian sejenis yang dilakukan oleh penulis lain belum pernah ada yang mengangkat penelitian mengenai perilaku subordinasi, kekerasan dan penjinakan tokoh perempuan. Tujuan penelitian ini yaitu menunjukkan unsur-unsur intrinsik dan ekstrinsik dalam novel Putri I karya Putu Wijaya, perilaku subordinasi, kekerasan dan penjinakan (Cooptation) tokoh perempuan.

\section{Metode}

Rancangan yang digunakan dalam penelitian ini adalah deskriptif. Adapun jenis penelitian ini adalah deskriptif kualitatif. Dalam penelitian ini, nantinya ditemukan kutipankutipan yang akan ditulis pada kartu data untuk memberikan gambaran penyajian 
penelitian tersebut. Kartu data tersebut akan dideskripsikan atau dipaparkan apa adanya sehingga akan diketahui unsur intrinsik dan ekstrinsik serta perilaku subordinasi, kekerasan, dan penjinakan (cooptation) tokoh perempuan dalam novel Putri I karya Putu Wijaya.

Subjek penelitian ini adalah novel yang berjudul Putri I karya Putu Wijaya. Novel ini diterbitkan oleh PT Pustaka Graffiti tahun 2004. Putri merupakan novel terpanjang dalam sejarah sastra Indonesia modern pada masanya, yakni setebal 1129 halaman yang dibagi menjadi dua jilid masing-masing terrdiri dari 533 dan 596 halaman. Sedangkan objek penelitian adalah unsur intrinsik dan ekstrinsik yang terdapat dalam novel Putri I serta kutipan kalimat yang menunjukkan adanya perilaku subordinasi, kekerasan, dan penjinakan (cooptation) tokoh perempuan dalam novel Putri I karya Putu Wijaya dengan menggunakan kajian feminisme.

Teknik pengumpulan data yang digunakan dalam penelitian ini adalah teknik dokumentasi. Adapun yang penulis lakukan untuk memeroleh data yaitu dengan cara membaca novel secara berulang-ulang, kemudian mencatat kutipan-kutipan tentang representasi ketidakadilan dan representasi perjuangan tokoh perempuan dalam novel Putri I. Setelah data terkumpul, penulis melanjutkan untuk mendeskripsikan data tersebut hingga mendapat kesimpulan.

Alat pengumpulan data yang penulis gunakan adalah penulis sendiri sebagai instrumen utama dan kartu pencatatan data berupa catatan yang berisi kutipan kalimat sesuai dengan permasalahan dalam penelitian pada novel Putri I karya Putu Wijaya. Data yang telah dikumpulkan selanjutnya diklasifikasikan sesuai dengan masalah penelitian yang meliputi perilaku subordinasi, kekerasan, dan penjinakan (cooptation) tokoh perempuan dalam novel Putri I karya Putu Wijaya. Teknik pengolahan data dalam penelitian ini adalah menggunakan teknik langsung dan penulis sendiri sebagai instrumen utamanya. Adapun Langkah dalam teknik pengolahan data yang dilakukan, yaitu pemilahan dan juga penyusunan klasifikasi data berupa kutipan tentang perilaku subordinasi, ekkerasan, dan penjinakan (cooptation) tokoh perempuan dalam novel Putri I karya Putu Wijaya.Kemudian dilakukan penyuntingan data dan juga pemberian kode data yang telah didapat. Selanjutnya dilakukan konfirmasi data yang memerlukan verifikasi data dan pendalaman data. Langkah terakhir dilakukan analisa data sesuai dengan konstruksi pembahasan hasil penelitian hingga mendapatkan kesimpulan.

\section{Hasil dan Pembahasan}

Tema yang terdapat dalam novel Putri I karya Putu Wijaya adalah tentang permasalahan gender yang mengarah pada sikap patriarki yang memandang bahwa perempuan tidak memiliki hak berbicara dan adanya kekerasan fisik serta kekerasan seksual. Putri merupkan tokoh utama dalam novel.Putri digambarkan seorang perempuan yang pintar, berani, tegas, dan tidak mudah menyerah. Sifat tokoh Putri digambarkan pada kutipan berikut :

"Saya saja berani, masak yang laki-laki tidak," kata Putri. "Sejarah kita baru ditulis, dan yang menulisnya adalah kita sendiri. Sama sekali bukan dituliskan orang lain. Apalagi tujuannya hanya membuat kita hidup terpenjara dalam tabu-tabu yang tak rasional tulis Putri dalam pengantar skripsinya, mengutip ucapan seorang pengarang lokal yang menjadi favoritnya. (Putri, hal.4)

Kutipan tersebut menggambarkan tokoh Putri yang berani. Dilihat dari kalimat "Saya saja berani, masak yang laki-laki tidak," kalimat tersebut diungkapkan saat Putri berusaha meyakinkan penduduk Meliling agar mau mengubah pola pikir kearah yang lebih maju dan masuk akal.

Penokohan yang dilakukan oleh pengarang salah satunya dengan menggambarkan melalui fisik tokoh (cara berpakaian, tinggi badan, cantik atau jelek dan cara berpakaian). 
Bukan hanya rambut yang harus dipotong, segala kebiasaanmu yang tidak perlu juga harus dibuang," kata Nelly. "Kebiasaan memakai pakaian terlalu sederhana juga harus ditinggalkan. Kamu memiliki mata, hidung, bibir, dan buah dada yang bagus. Pinggul kamu merangsang sekali... (Gadis Pantai, hal. 65)

Kutipan tersebut menggambarkan Putri yang sederhana dan memiliki bentuk wajah serta tubuh yang bagus. Novel Putri I karya Putu Wijaya menggunakan alur campuran. Berdasarkan konsep alur campuran itu ditemukan kesesuaian terhadap cerita yang terdapat dalam novel Putri I.Novel Putri I karya Putu Wijaya terdapat tiga latar yang akan diuraikan dalam kutipan berikut :

Latar waktu yaitu "Ketika Merta terkena penumpasan pada masa G-30-S, namng Merta meminta agar ia diperbolehkan melaksanakannya" (Putri, hal.44).

Latar Tempat, Perjalanan ke Puri Puncak Tabanan -21 km dari Denpasar- terasa cepat sekali. Putri sebenarnya masih ingin diam-diam di dalam mobil, menari-nari dalam pikirannya sendiri. Dengan ijazah di tangan, ia serta merta saja merasa menjadi orang lain. Kelelahannya selama 5 tahun bergumpal kembali. Semua itu bukan hanya hasil pekerjaannya sendiri ternyata, melainkan hasil kerja patungan dengan semua orang yang sudah membantunya. (Putri, 11)

Latar Suasana, Putri kembali menangis di dalam kamar itu. la merasa tak berdaya dipermainkan oleh nasib. Seakan-akan nasib memang mahluk kejam yang sengaja diciptakan untuk mendera orang miskin dari desa. Kebahagiaan menjadi begitu mahalnya, karena setiap kerat meminta bayaran yang terlalu tinggi. Terutama perempuan, harus membayarnya dengan darah dan air mata (Putri, hal. 13)

Gaya bahasa yang terkandung dalam novel Putri I karya Putu Wijaya, lebih banyak menggunakan majas personifikasi dibandingkan dengan majas lainnya seperti metafora, simile, dan hiperbola. Adapun datanya sebagai berikut.

Majas personifikasi, Jero mangku, bapak Putri, juga sering mengingatkan bahwa perut itu bukan kuburan untuk membuang sampah. (Putri, hal. 6). Sambal jalan, Putri kembali membongkar apa yang sudah terjadi. Rasanya begitu banyak yang nimbrung, mengurangi kebahagiaannya. (Putri, hal. 37). Kain Men Putri tambah merosot. Tersibak pahanya, begitu keci dan layu. Sama sekali tidak menyisakan sebagai Ni Nyoman Rampig, kembang desa di masa lalu. Rambutnya terurai seperti ilalang diamuk badai, menngantam muka suaminya. (Putri, hal.41). Mangku Puseh terhenyak, lalu mengunci percakapan di situ. (Putri, hal 43). Nenek Putri meniupkan penafsiran itu ke arah Men Sadra lewat telinga tetangga. Tentu saja Men Sadra gamuk. Bagaikan ular kobra yang baru ganti kulit, ia keluar dari rumahnya. (Putri, hal 50). Mangku Puseh kemudian diam seperti tenggelam dengan kata-katanya sendiri. (Putri, hal. 50).

Majas metafora, Putri diam-diam mencuri melihat beberapa garis muka ibunya semakin dalam.Rambut putihnya juga sudah bertambah.Bagimana tidak. Wanita ini lah yang sudah banting tulang untuknya. (Putri, hal 36). Bapa tidak mendengar apa yang kamu katakan, Luh, kata mangku Puseh. Bapa tuli dan buta. Bapa sudah lama mati. Badan Bapa sudah tidak ada lagi. Keinginanpun sudah hilang.Yang ada Cuma kewajiban.Bapa hanya sebuah jalan yang jadi jembatan warga Meliling untuk menyebrangi selokan. Sebaiknya Bapa jangan diganggu, karena tidak akan bias lagi terganggu. Nanti kamu sakit. (Putri, hal40). Putri, katakan pada dosen-dosen di kampus, hidup yang sebenarnya tidak bisa diecahkan dengan ijazah. IImu hanya celana dalam. Tulis Oka. (Putri, hal.48).

Majas Simile, Kematiannya yang tiba-tiba itu seperti kentut dalam kelas yang sedang ulangan umum.Membuat orang kaget. (Putri, hal. 37).

Majas Hiperbola, Semua lalu mencoba mencoba menggapai lebih jauh.Tetapi mereka tetap tak dapat menangkap sepenuhnya dari keping-keping yang bertebaran itu.Hasilnya hanya sebuah tebakan.(Put ri, hal 39). Oka tenggelam dalam musik yang ditumpahkan Walkman-nya. Telepon yang berdering-dering di depan hidungnya dibiarkan saja menjerit-jerit. 
Tokoh utama dalam novel Putri I adalah Putri.Penceritaan karakter utama dalam novel dituturkan secara umum oleh pengarang. Hal tersebut nampak jelas dengan penyebutan karakter utama oleh pengarang yaitu dengan nama Putri, seperti pada kutipan di bawah ini:

Kasihan.Saya belikan roti kembung. Putri memasukkan makanan lembut kesukaan orang tua itu ke dalam toples. Ketika ia menoleh, ibunya sudah pergi ke dapur hendak memasak air. Putri hampir saja mau melarang, tetapi kemudian ia tak sampai hati. Itu merupakan kebanggaan seorang ibu. la sudah belajar menghargai hal-hal yang tak masuk akal, setelah gagal untuk memusnahkannya. Itu sebuah cerita sendiri yang tak mudah dilaluinya. (Putri, Hal. 3)

Data cuplikan Novel Putri -I pada kalimat pertama mengandung kata ganti orang pertama dalam penyebutan kata (saya), oleh pengarang tokoh utama yang menjadi pusat cerita. Data cuplikan novel berikutnya juga menyebutkan tokoh utama dengan sebutan nama sendiri (Putri) dan kata ganti ia, dan - nya. Hal tersebut berarti pengarang menggunakan pronomina persona ketiga (Putri, ia, -nya) untuk menyebutkan tokoh utama. Penceritaan dengan penyebutan tokoh utama yang demikian merupakan teknik penerapan sudut pandang ekstern.

Amanat yang terdapat dalam novel Putri I disampaikan pengarang melalui tokoh Putri.Pengarang mendeksripsikan cerita untuk mengajak pembaca melihat lebih jelas tokoh perempuan dalam menghadapi konflik yang timbul karena tradisi, adat bahkan keluarga. Sosok perempuan yang harus mampu untuk berpikir lebih modern dan tegas serta kuat dalam menghadapi tiap permasalahan yang menimpanya.

\section{Unsur ekstrinsik dalam Novel Putri I}

Biografi Putu Wijaya, Putu Wijaya adalah sastrawan Indonesia yang produktif menghasilkan karya sastra, ragam karyanya berupa cerpen, novel, drama, maupun skenario film. Produktivitasnya sebagai sastrawan diimbangi pula oleh kualitas karya yang dihasilkan.

Faktor Religi, Sudah, kalau kenyang jangan diteruskan. Tidak baik kalau tidak dengan rasa hormat kepada makanan (Putri, Hal. 6). Kutipan teks tersebut menyatakan bahwa faktor religi terdapat pada kalimat Tidak baik kalau tidak dengan rasa hormat kepada makananyang diucapkan Men Putri ketika menemani Putri makan. Hal ini merupakan bukti adanya kepercayaan yang sangat kental walau terhadap makanan sekali pun, agar manusia selalu mampu bersyukur.

Faktor Politik, Karena rasa malu, seorang ayah telah membunuh anak kandungnya dengan tangannya sendiri. la mengganggap itu kewajibannya terhadap desa. Namanya Nang Merta. la seorang tukang patri yang sederhana dan baik. Tak pernah jahat dan berbicara kasar kepada orang lain. Tetapi anak tunggalnya yang bernama I Wayan Merta, aktif sekali sebagai anggota kelompok jangger yang berkampanye untuk partai komunis di masa lalu. (hal. 44). Kutipan teks di atas terkandung faktor politik. Seorang ayah yang harus membunuh anak tunggalnya karena sang anak ikut dalam partai politik. Ini merupakan bukti bahwa sejak dulu politik tidak pernah memandang kawan dan lawan bahkan hubungan sedarah sekali pun.

Faktor Adat, Dalam keadaan seperti itu, Men Putri Muncul, dengan gigih mendesak untuk menandai saat tutug kelih Nyoman dengan nelaksanakan upacara potong gigi. Putri kembali tak sanggup mengatakan tidak. (Putri, hal.179). Faktor adat yang terdapat dalam kutipan tersebut ada pada bagian tutug kelih dan upacara potong gigi. Upacara Tutug Kelih biasa dilaksanakan oleh umat Hindu bagi anak-anak perempuan yang sudah beranjak dewasa, ditandai dengan haid pertama. Selain upacara Tutug Kelih, dilanjutkan upacara selanjutnya yaitu potong gigi/mepandes/mesangih.

Perilaku Subordinasi, Penelitian ini memeroleh hasil berupa perilaku subordinasi sebanyak 5 data.Novel Putri I karya Putu Wijaya ini memaparkan perilaku subordinasi yang dialami oleh tokoh perempuan. Perilaku subordinasi ini merupakan sikap yang menempatkan perempuan pada posisi yang lemah dan tidak menguntungkan. Selain itu, 
perempuan dianggap tidak memiliki hak untuk berbicara dan mengajukan pendapat sekalipun itu untuk menunjukkan kebenaran.

Kekerasan, Penelitian ini memeroleh hasil berupa perilaku kekerasan, baik kekerasan fisik maupun kekerasan verbal sebanyak 5 data.Kekerasan yang terdapat dalam novel Putri I karya Putu Wijaya berupa kekerasan verbal berupa ungkapanungkapan yang merendahkan perempuan, kekerasan fisik berupa pelecehan seksual secara langsung atau pun terselubung dan pelecehan secara psikis, yaitu pelecehan yang dilakukan dengan menyakiti hati atau bathin tokoh dalam cerita.Kekerasan yang diuraikan dalam cerita sering terjadi di masyarakat.

Penjinakan (Cooptation), Hasil penelitian berupa perilaku penjinakan yang dialami oleh tokoh perempuan dalam novel Putri karya Putu Wijaya didapat sebanyak 8 data.Hasil penelitian mengenai perilaku penjinakan tokoh perempuan yang penulis lakukan merupakan salah satu perilaku yang terjadi dalam kehidupan manusia.Penjinakan yang dimaksud dalam hal ini, merupakan ketidakadilan yang dialami tokoh perempuan berupa perilaku adanya maksud yang tersembunyi di balik kebaikan yang ditunjukkan oleh tokoh lainnya terhadap tokoh perempuan. Korban penjinakan akan sangat dirugikan sehingga mengurangi rasa percaya terhadap pelakunya. Perbedaan dan pembagian gender dengan segenap manifestasinya mengakibatkan tersosialisasinya citra posisi, kodrat, dan penerimaan wanita yang ada.

Berdasarkan hasil dan pembahasan penelitian yang telah penulis lakukan, maka kesimpulan dari data-data yang diperoleh yaitu, unsur-unsur yang terdapat dalam novel Putri I, yaitu unsur intrinsik yang mencangkup tema. Tema yang digunakan dalam novel adalah tentang permasalahan gender dengan menggunakan alur campuran. Adapun latar (tempat, waktu, suasana) terdapat dalam novel untuk menghidupkan cerita.

Tokoh utama dalam novel adalah Putri. Seorang Sarjana Sastra pertama dari Desa Meliling yang digambarkan sebagai seorang yang berani, mandiri, kuat, pintar, cantik dan sederhana. Selanjutnya gaya bahasa yang digunakan dalam novel penulis ambil secara acak yang meliputi majaspersonfikasi sebanyak $50 \%$, hiperbola sebanyak $16 \%$, simile $8 \%$, metafora sebanyak $25 \%$. Amanat yang terdapat. Sedangkan unsur ekstrinsik terdapat biografi pengarang Putu Wijaya, faktor adat, tradisi, religi, dan politik.

Perilaku ketidakadilan gender berupa subordinasi kekerasan, dan penjinakan tokoh perempuan dalam novel Putri I diperoleh hasil sebanyak 18 data, yaitu subordinasi 5 data $(28 \%)$, kekerasan 5 data $(28 \%)$, dan yang paling banyak adalah penjinakan sebanyak 8 data (44\%).

Penelitian dalam Novel Era Revolusi Dan Reformasi yang dilakukan oleh Ridwan, Widiasturi, \& Yulianeta (2016) menyatakan bahwa gejolak historis yang ditampilkan ketiga novel tersebut menyajikan sebuah polemik kehidupan masa revolusi dengan suasana mempertahankan kemerdekaan, serta semangat baru dalam reformasi sebagai kritik atas rezim orde baru yang bercorak militer. Era revolusi dan reformasi yang ditulis Pram menyiratkan sebuah visi dunianya bahwa seorang perempuan harus memiliki hak yang sama dalam kehidupan. Perempuan boleh memilih untuk mengakses ranah publik dan berkiprah untuk mengembangkan potensi dirinya. Para perempuan yang digambarkan dalam novel Perawan Remaha dalam Cengkeraman Militer juga memiliki ketahanan yang luar biasa dalam menghadapi fasisme Jepang dan menanggung dampak dari kejadian tersebut. Hal itu dibuktikan dengan beberapa perempuan yang melarikan diri dan berusaha melawan untuk tidak dijadikan "wanita penghibur" serdadu Jepang.

Penelitian yang dilakukan Sungkowati (2017) yang mendeskripsikan gambaran perempuan Jawa, Dayak, Tionghoa, dan Jepang dalam novel-novel Lan Fang dengan perspektif feminis. Hasil penelitian menyatakan bahwa perempuan dalam novel-novel Lan Fang tidak digambarkan dengan citra yang sama. Perempuan Jawa digambarkan paling negatif, sedangkan perempuan Tionghoa digambarkan dengan citra yang paling positif. Di antara keduanya ada perempuan Dayak yang gambarannya cenderung negatif dan perempuan Jepang yang citranya cenderung positif. Hal itu menunjukkan keberpihakan Lan Fang yang berasal dari latar belakang Tionghoa pada perempuan kelompok etniknya. 
Penelitian yang dilakukan oleh Wahyuni et al., (2019) mengenai kekerasan Simbolik dalam Novel Indonesia menyatakan mekanisme kekerasan simbolik terdiri atas eufemisme berupa belas kasih, pemberian, penolakan secara halus. Mekanisme sensorisasi berupa pelestarian moral posiif berupa kehormatan dan kesopanan. Berdasarkan penelitian tersebut, maka dapat disimpulkan bahwa masih banyak perempuan yang diperlakukan tidak adil. Beberapa perempuan berusaha melawan ketidakadilan. Perempuan dapat mengembangkan potensi dirinya.

\section{Simpulan}

Unsur-unsur yang terdapat dalam novel Putri I, yaitu unsur intrinsik yang mencangkup tema. Tema yang digunakan dalam novel adalah tentang permasalahan gender dengan menggunakan alur campuran. Adapun latar (tempat, waktu, suasana) terdapat dalam novel untuk menghidupkan cerita. Gaya bahasa yang digunakan dalam novel penulis ambil secara acak yang meliputi majaspersonfikasi, hiperbola sebanyak, simile, dan metafora. Unsur ekstrinsik terdapat biografi pengarang Putu Wijaya, faktor adat, tradisi, religi, dan politik. Perilaku ketidakadilan gender berupa subordinasi kekerasan, dan penjinakan tokoh perempuan dalam novel Putri I.

\section{Daftar Pustaka}

Burhanuddin, Susiawati, \& Ernawati. (2017). Kemampuan Menulis Karya Sastra Berbahasa Jerman Mahasiswa Program Studi Pendidikan Bahasa Jerman FBS UNM (Kajian Struktural). Jurnal Pendidikan Bahasa Dan Sastra, 1(2). Retrieved from https://ojs.unm.ac.id/eralingua/article/view/4407

Daeng, K. (2012). Gender Dalam Syair Kelong Makassar. RETORIKA: Jurnal Bahasa, Sastra, Dan Pengajarannya, 8(1). Retrieved from https://ojs.unm.ac.id/index.php/retorika/article/view/511

Fatah, R. A., Widodo, S. T., \& Rohmadi, M. (2018). Pendidikan Karakter Dalam Novel Mahamimpi Anak Negeri Karya Suyatna Pamungkas Tinjauan Psikologi Sastra. Jurnal Gramatika: Jurnal Penelitian Pendidikan Bahasa Dan Sastra Indonesia, 4(1). https://doi.org/https://doi.org/10.22202/jg.2018.v4i1.2412

Helda, T. (2016). Harga Diri Perempuan Minangkabau Dalam Novel Di Bawah Lindungan Ka'bah Karya Hamka. Jurnal Gramatika: Jurnal Penelitian Pendidikan Bahasa Dan Sastra Indonesia, 2(1). https://doi.org/https://doi.org/10.22202/jg.2016.v2i1.1409

Kurniawan, A., \& Suyitno, S. A. R. (2020). Javanese Women' Patriotism In The Ketoprak Manuscript "Kyai Kala Gumarang." RETORIKA: Jurnal Bahasa, Sastra, Dan Pengajarannya, 13(2). https://doi.org/https://doi.org/10.26858/retorika.v13i2.12478

Liasna, T., \& Ansari, K. (2016). Persepektif Gender dalam Dwilogi Novel Padang Bulan Cinta di dalam Gelas Karya Andrea Hirata: Kritik Sastra Feminisme serta Relevansinya sebagai Bahan Bacaan Sastra di SMA. Jurnal IImiah IImu-IImu Humaniora, 15(2). https://doi.org/https://doi.org/10.24036/jh.v15i2.6587

Mulyaningsih, I. (2015). Kajian Feminis pada Novel Ronggeng Dukuh Paruk dan Perempuan Berkalung Surban. Indonesia Languange Education and Literature, 1(1). https://doi.org/http://dx.doi.org/10.24235/ileal.v1i1.75

Putri, R. A. (2020). Dekonstruksi Girl Power dalam Novel The Devil Wears Prada Karya Lauren Weisberger. Poetika: Jurnal IImu Sastra, 8(1). https://doi.org/https://doi.org/10.22146/poetika.v8i1.56540

Qadriani, N. (2016). Gaya Hidup Dalam Teenlit Indonesia: Kajian Semiotika Terhadap Novel My Friends My Dream Karya Ken Terate Dan Glam Girls Karya Nina Ardianti. RETORIKA: Jurnal Bahasa, Sastra, Dan Pengajarannya, 9(1). 
https://doi.org/https://doi.org/10.26858/retorika.v9i1.3793

Ridwan, I., Widiasturi, A., \& Yulianeta, Y. (2016). Pandangan Pramoedya Terhadap Resistansi Perempuan Dalam Novel Era Revolusi Dan Reformasi. Adabiyyat: Jurnal Bahasa Dan Sastra, 15(1). https://doi.org/https://doi.org/10.14421/ajbs.2016.15104

Sari, K. M. K. (2017). Transformasi Pewayangan Dalam Tokoh Wisanggeni Sebuah Analisis Intertekstual Novel Wisanggeni Sang Buronan Karya Seno Gumira Adjidarma Dengan Komik Lahirnya Bangbang Wisanggeni Karya Ra. Jurnal Gramatika: Jurnal Penelitian Pendidikan Bahasa Dan Sastra Indonesia, 3(2). https://doi.org/https://doi.org/10.22202/jg.2017.v3i2.1872

Sungkowati, Y. (2017). Perempuan Jawa, Dayak, Tionghoa, Dan Jepang Dalam NovelNovel Lan Fang (Javanese, Dayak, Chinese, And Japanese Women In Lan Fang Novels). Widyaparwa (Jurnal Ilmiah Kebahasaan Dan Kesastraan), 45(2). https://doi.org/https://doi.org/10.26499/wdprw.v45i2.151

Susanti, E. (2013). Analisi Ketidakadilan Gender Pada Tokoh Perempuan Dalam Novel Kupu-kupu Malam Karya Achmad Munif. Jurnal Artikulasi, 10(2).

Ulfah, D., Garim, I., \& Sultan, S. (2019). Bias Gender Dalam Buku Teks Pelajaran Bahasa Indonesia Sekolah Menengah Atas. RETORIKA: Jurnal Bahasa, Sastra, Dan Pengajarannya, 12(2). https://doi.org/https://doi.org/10.26858/retorika.v12i2.8935

Wahyuni, S., Supratno, H., \& Kamidjan, K. (2019). Kekerasan Simbolik Dalam Novel Indonesia. RETORIKA: Jurnal Bahasa, Sastra, Dan Pengajarannya, 12(2). https://doi.org/https://doi.org/10.26858/retorika.v12i2.8833 